\title{
A NEW GENERATION SOLAR PHOTOVOLTAIC INTEGRATED SYSTEM FOR ELEVATOR DOOR OPERATION
}

\author{
Bidrohi Bhattacharjee $^{1^{*}}$, Pradip Kumar Sadhu ${ }^{1}$, Ankur Ganguly ${ }^{2}$ and \\ Ashok Kumar Naskar ${ }^{2}$ \\ ${ }^{1}$ Department of Electrical Engineering, Indian Institute of Technology (Indian \\ School of Mines), Dhanbad, Jharkhand-826004, India \\ ${ }^{2}$ Department of Electrical Engineering, Techno International Batanagar, \\ Kolkata-700141, India \\ "onlybidrohi@gmail.com
}

\begin{abstract}
This paper proposes the concept of a solar photovoltaic (SPV) integrated system for operation of an elevator door motor. The system uses a solar charge controller so that a steady voltage is supplied to the elevator DC shunt motor. The charge controller also protects the system against overcharging and over discharging. The integrated system has been simulated using PSIM and it has also been implemented in real life as a real life prototype to perform experiments. The experimental results have been captured and analyzed to understand the usefulness of such system.
\end{abstract}

Keywords - Battery, Charge Controller, DC Shunt Motor, Elevator, Solar Photovoltaic (PV) System, Sunlight

\section{INTRODUCTION}

Renewable energy sources have started showing great potential as an alternative source of energy and are playing a vital role in minimizing greenhouse gas emissions. Out of different forms of renewable energy sources, solar energy is most widely used and is a major contributor to renewable power generation leading to generation of electricity in solar photovoltaic (SPV) modules [1]-[3], [20].

Use of solar energy for water pumping system is described in [4]. Solar energy based systems can be categorized into standalone and grid interfaced systems. Energy storage management is the key component for standalone solar energy conversion system, but it is not free from various problems as discussed in [5]-[8]. On the contrary, grid interfaced systems are more preferred where the grid acts as an energy buffer, and the power generated can be fed to the grid. Few grid interfaced SPV systems have been identified to address the issues related to islanding, intermittency, modelling, etc [9]-[11]. SPV is a most promising environment friendly power generation technology with almost no maintenance and running costs [12], [13]. A lot of grid interfaced PV systems have been proposed in the past [14], [15]. The grid interfaced PV system with different converter topologies are reported in [16], [17], whereas, voltage source converter (VSC) is still preferred over other converter topologies for PV system due to its simplicity and wide range of operating frequencies.

Received: May 27, 2019

Reviewed: August 28, 2019

Accepted: September 2, 2019

* Corresponding Author

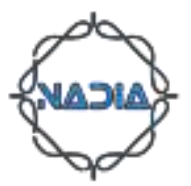


This paper describes the design and operation of an integrated solar photovoltaic system used to generate electricity required for running the elevator door motor. The SPV module contains some photovoltaic cells in series-parallel combination that will help achieve the required voltage. The solar photovoltaic panel absorbs the solar energy to convert it into electrical energy and produces the DC output voltage. But the output DC voltage doesn't remain constant due to change in sunlight throughout the day. Hence the electrical energy produced needs to be stored in a battery to generate a steady voltage for any load. A solar charge controller is used to protect the battery against overcharging and over discharge. It also stops the current flowing back to solar panel during night. The controlled output voltage has been applied to the DC shunt motor used as the drive motor for elevator door operation.

As part of this study, an integrated system has been built that is capable of running the DC shunt motor for elevator door operation using solar energy through simulation with PSIM. The simulated model has also been studied in real time and the results are discussed here.

In this paper, integrated system configuration is outlined in Section 2. Section 3 includes the simulation. Experimental results are discussed in Section 4 and the paper is concluded in Section 5.

\section{SOLAR PV INTEGRATED SYSTEM CONFIGURATION}

A Photovoltaic (PV) system comprises an array of solar panels that convert solar energy to electricity. PV cells, made up of semiconductor materials are arranged to form a solar panel. The capacity of a PV cell depends on cell efficiency and fill factor. The PV cell efficiency $(\eta)$ is defined as the ratio of peak power output to input solar power and is calculated as [18].

$$
\eta=\frac{V_{m x p} I_{m x p}}{A I}
$$

Where

$V_{m x p}=$ Voltage at peak power

$I_{m x p}=$ Current at peak power

$A=$ Area of solar cell

$I=$ Solar intensity per square meter

When the PV cell delivers maximum power for favorable environmental conditions of irradiance and temperature, the efficiency will be highest. The Fill Factor (Ff) is defined as the ratio of maximum power from the solar cell to the product of open-circuit voltage $\left(\mathrm{V}_{\mathrm{oc}}\right)$ and short-circuits current density $\left(\mathrm{J}_{\mathrm{sc}}\right)$ and is expressed as [19].

$$
F_{f}=\frac{V_{m x p} I_{m x p}}{V_{o c} J_{s c}}
$$

The fill factor along with $\mathrm{V}_{\mathrm{oc}}$ and $\mathrm{J}_{\mathrm{sc}}$, determine the maximum power from a solar cell. For a normal silicon PV cell the Fill factor is around $80 \%$. 


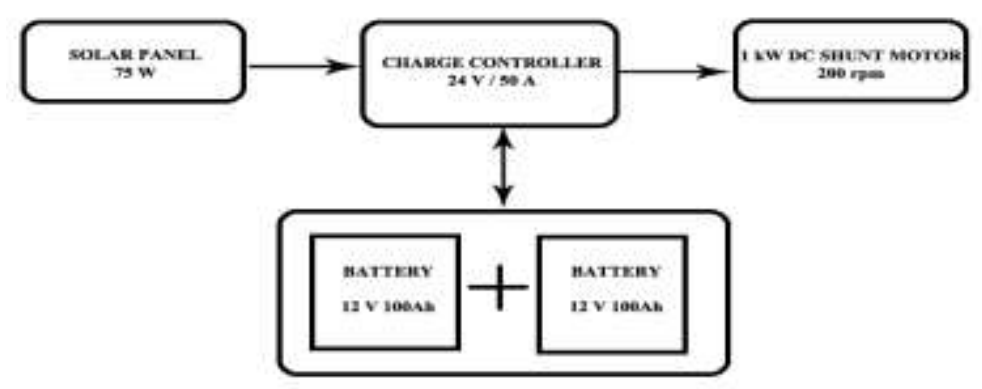

Fig. 1 Block diagram of solar powered system for elevator door operation
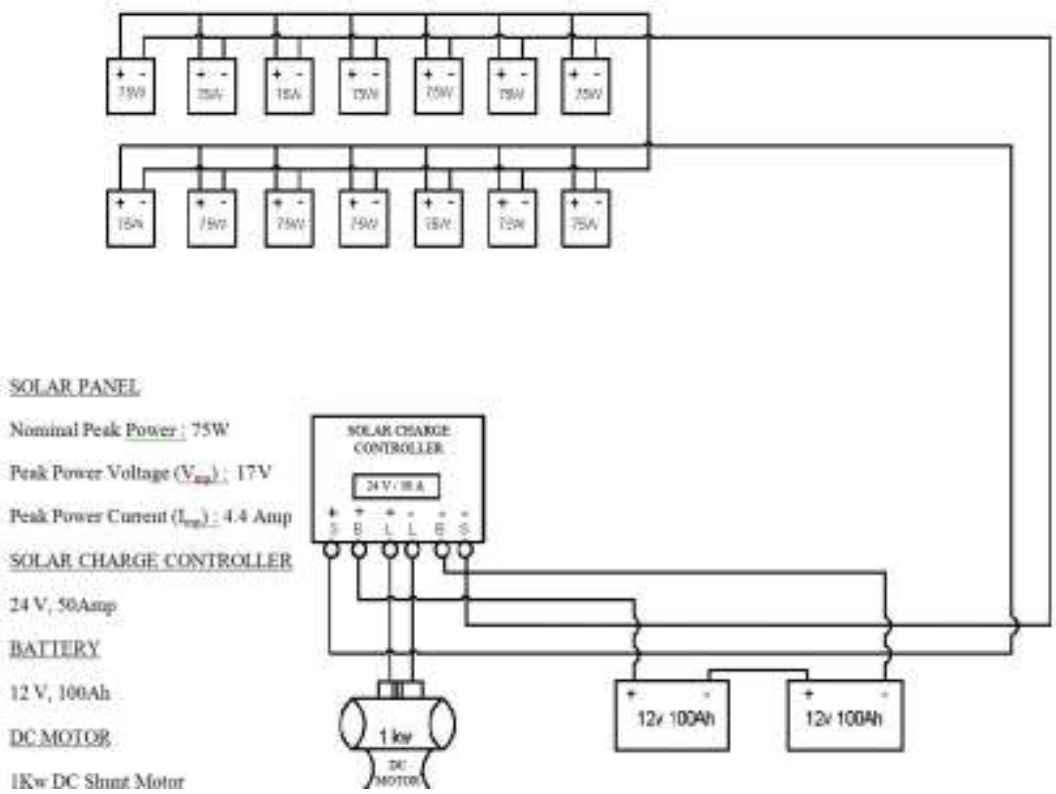

Fig. 2 Integrated PV system for elevator door operation

Here, the integrated photovoltaic (PV) system consists of PV panel, a charge controller, batteries, the elevator door motor and elevator door. Fig. 1 shows the integrated system. This integrated system aims at maintaining a steady rotation and speed control of the DC shunt motor always for proper functioning of the elevator door even during night. The solar PV panel is responsible for generating electrical energy from solar energy to produce the DC output voltage. This DC voltage varies due to change in sunlight throughout the day. So batteries are required to generate a steady voltage for any load.

However, the shading effect impacts the performance of PV panels and the output energy of the panels is reduced due to the shading effect in presence of trees, clouds, buildings, etc. Shading can be uniform or non-uniform. For uniform shading, all solar cells in the panel receive same amount of insolation for a given amount of shading. So, decrease in sunlight is uniform across all the cells. In case of non-uniform shading, the cells in the panel don't receive same insolation. Thus, cells receiving lower irradiance will act as loads and behave in reverse biased condition leading to reduction in current, power and efficiency.

The solar panel block capable of minimizing the shading effect, contains 14 Tata BP Solar $75 \mathrm{~W}$ panels. The DC voltage from the photovoltaic system is fed to a couple of batteries so that the electrical energy is stored and can be used consistently. In order to drive the DC shunt motor through the batteries, two batteries of rating 12V/100Ah have been connected in series. The solar panels should deliver the charging voltage of $12 \pm 2 \mathrm{~V}$. 
Table I. Component specification

\begin{tabular}{|l|l|}
\hline Name of the component & Specification \\
\hline DC shunt motor & 1kW, 10 Amp, 200 rpm \\
\hline Solar charge controller & 24 Volt DC \& 50 Amp. 6 no Terminal (S+, S-, B+, B-, L+, L-). \\
& S+= solar (+ve), S- = solar (-ve), B+= Battery (+ve), B-= Battery (-ve), \\
& L+= Load (+ve), L-= Load (-ve) \\
\hline Solar panel & Nominal peak power (W): 75W \\
& Peak power voltage (Vmxp): 17V \\
& Peak power current (Imxp): 4.4 Amp \\
& Quantity: 14 Numbers \\
\hline Battery & 12Volt, 100Ah. Capacity@C20 in Ah. \\
& Quantity: 2 Numbers \\
\hline Cable & 10sq mm single core cable \\
\hline
\end{tabular}

However, when a battery is fully charged, it will not store incoming energy further. If charging still continues, the battery will degrade rapidly and may overheat. So there is a requirement of preventing the overcharging of batteries. PV panels work by pumping current through the batteries in one direction. At night, the panels will pass small current in reverse direction leading to slight discharge from batteries. So a charge controller is required to protect the system against overcharging and to block the reverse current. Few charge controllers protect the system from electrical overload as well. The controller provides two sets of terminals, one for battery connection and the other for motor connection. This system uses the $1 \mathrm{~kW}(24 \mathrm{~V}, 10 \mathrm{~A}) \mathrm{DC}$ shunt motor for elevator door operation, so the components have been chosen accordingly. Table I shows the specification of the components. Fig. 2 shows the components of the integrated PV system for elevator door operation. 14 solar panels are connected in series-parallel combination. The output of the combination is controlled by the solar charge controller. One set of controller outputs is connected to the batteries so that batteries don't over charge and no over discharge happens.

Another set of terminals of the controller are connected to the DC shunt motor so that almost a constant voltage is supplied to the motor. The DC shunt motor will perform the elevator door operation. The system also includes LCD display module and buttons to control the system.

During night time, the batteries will supply the power for elevator. The Battery rating (Ah) is $100 \mathrm{Ah}$. The Current drawn by motor is 10A. Thus, the backup duration will be for 10 hours, which is sufficient for night time use. Also, the door motor will not be used continuously throughout the day. Therefore, as per the requirement, two batteries will be sufficient to supply power needed by the elevator door during night time.

No switching is required for the elevator. It may run any time when there is need. Charge controller will stabilize the output voltage and will control the voltage level to a rated value facilitating the over voltage protection.

\section{SIMULATION OF THE SOLAR PV INTEGRATED SYSTEM}

The entire system has been simulated using PSIM. The system's performance has been studied for two conditions, viz., without the solar charge controller and with the solar charge controller. Fig. 3 displays the PSIM model of the integrated system without the solar charge controller.

The system in Fig. 3 has been studied for three conditions, i.e., during different time slots in a day. The system's performance has been simulated and the voltage and current waveforms have been obtained. Figures 4-6 show the corresponding voltage and current waveforms for those three conditions in absence of the solar charge controller. 


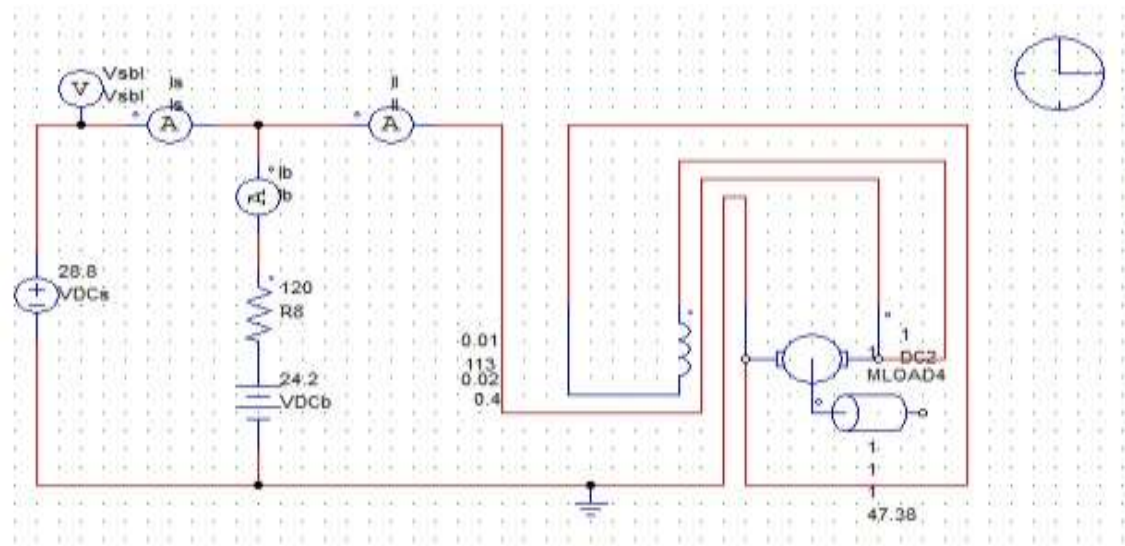

Fig. 3 Schematic Diagram of the Integrated System without Solar Charge Controller

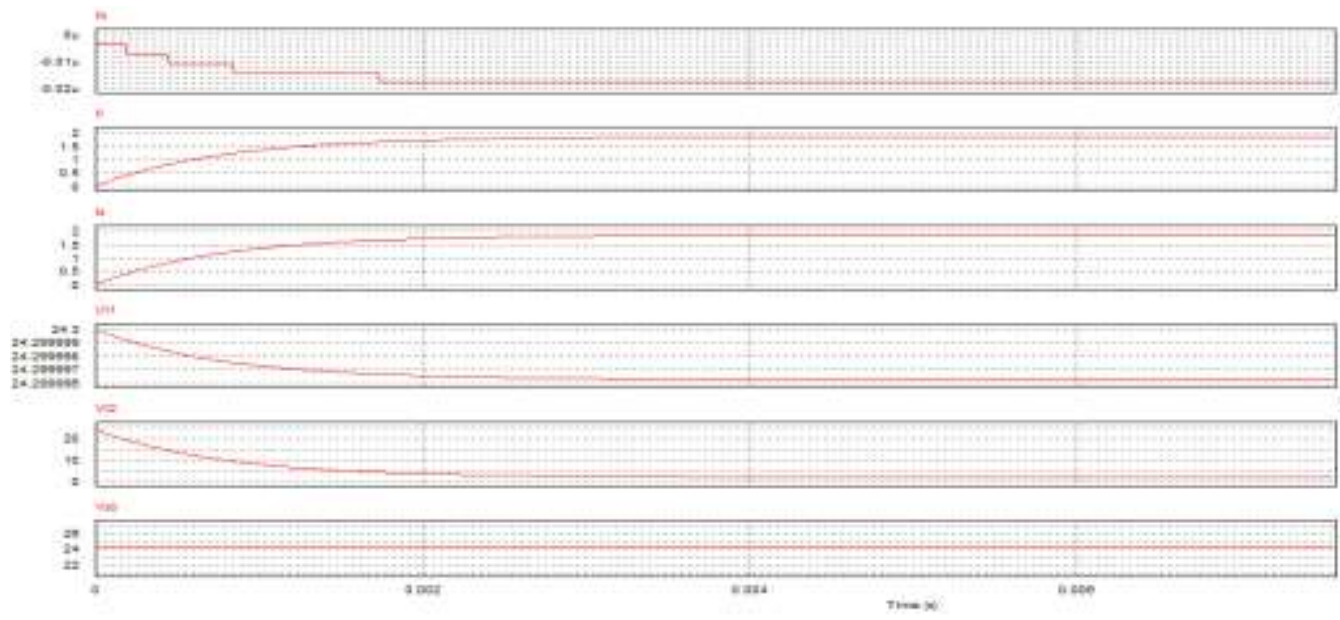

Fig. 4 Voltage and Current Waveforms with No Solar Charge Controller for Solar Panel Voltage 24.3 Volt

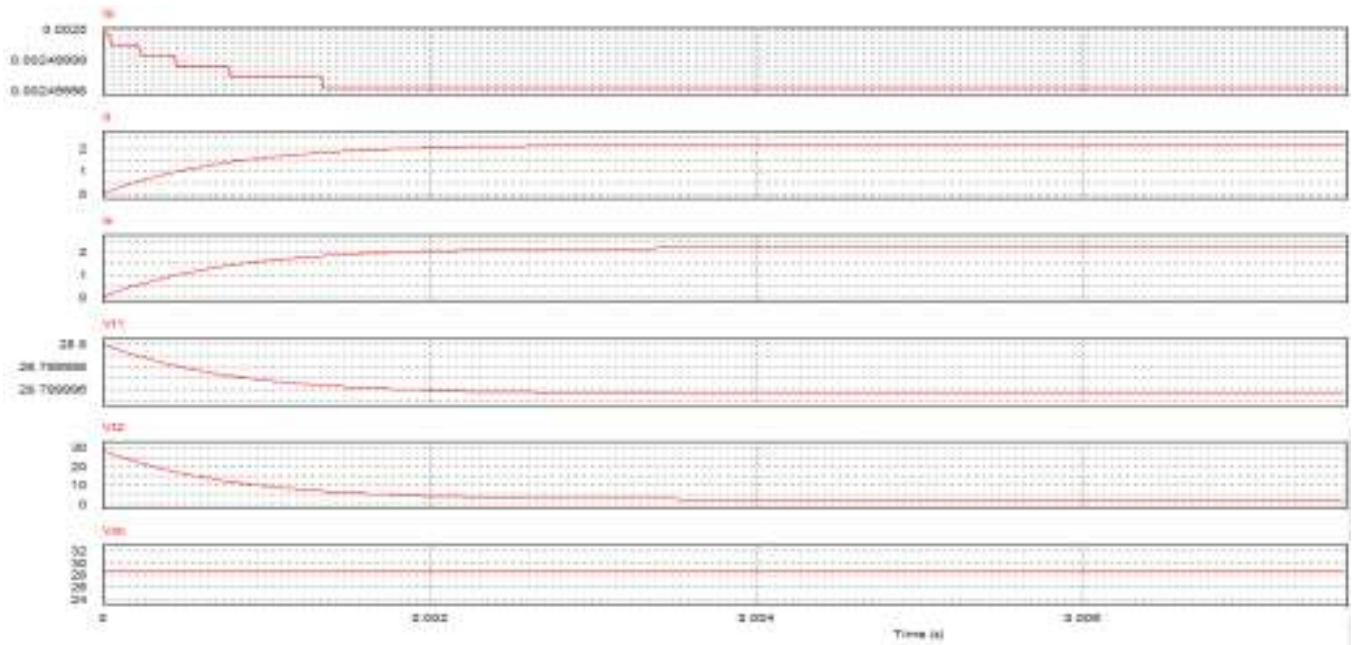

Fig. 5 Voltage and Current Waveforms with No Solar Charge Controller for Solar Panel Voltage 28.8 Volt 


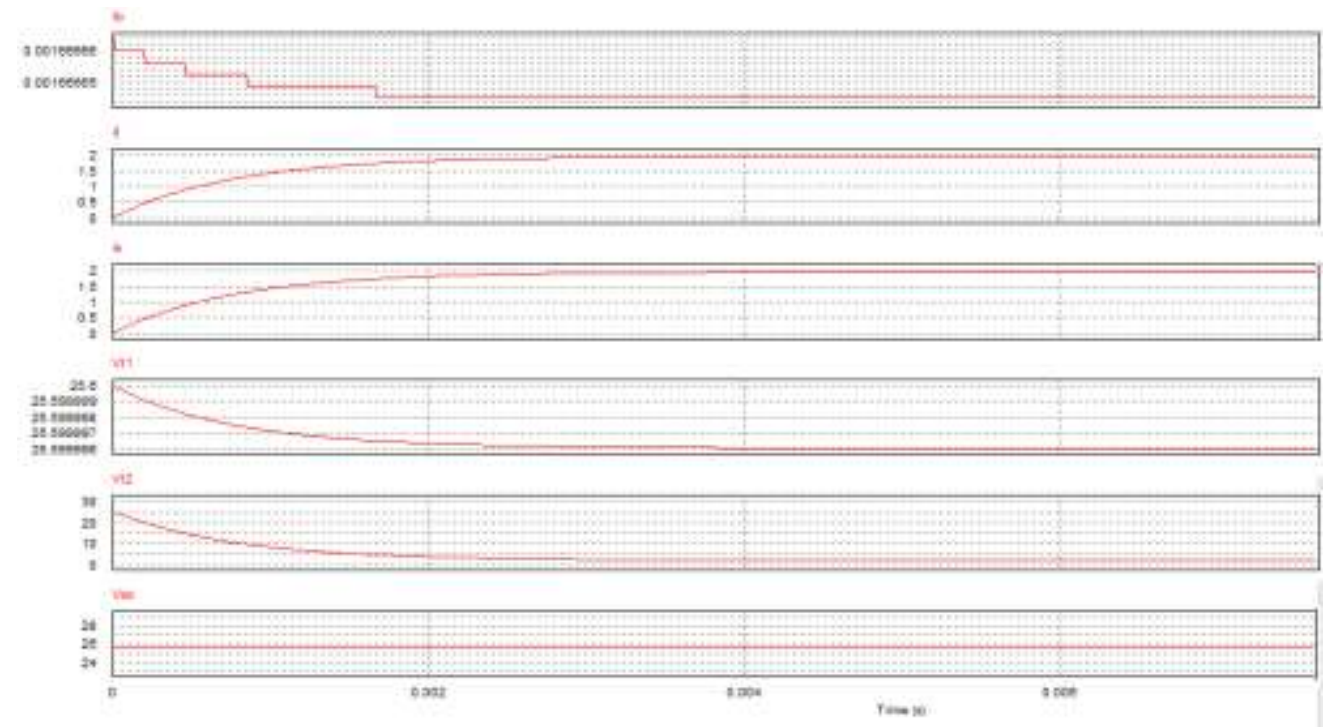

Fig. 6 Voltage and Current Waveforms with No Solar Charge Controller for Solar Panel Voltage 25.6 Volt

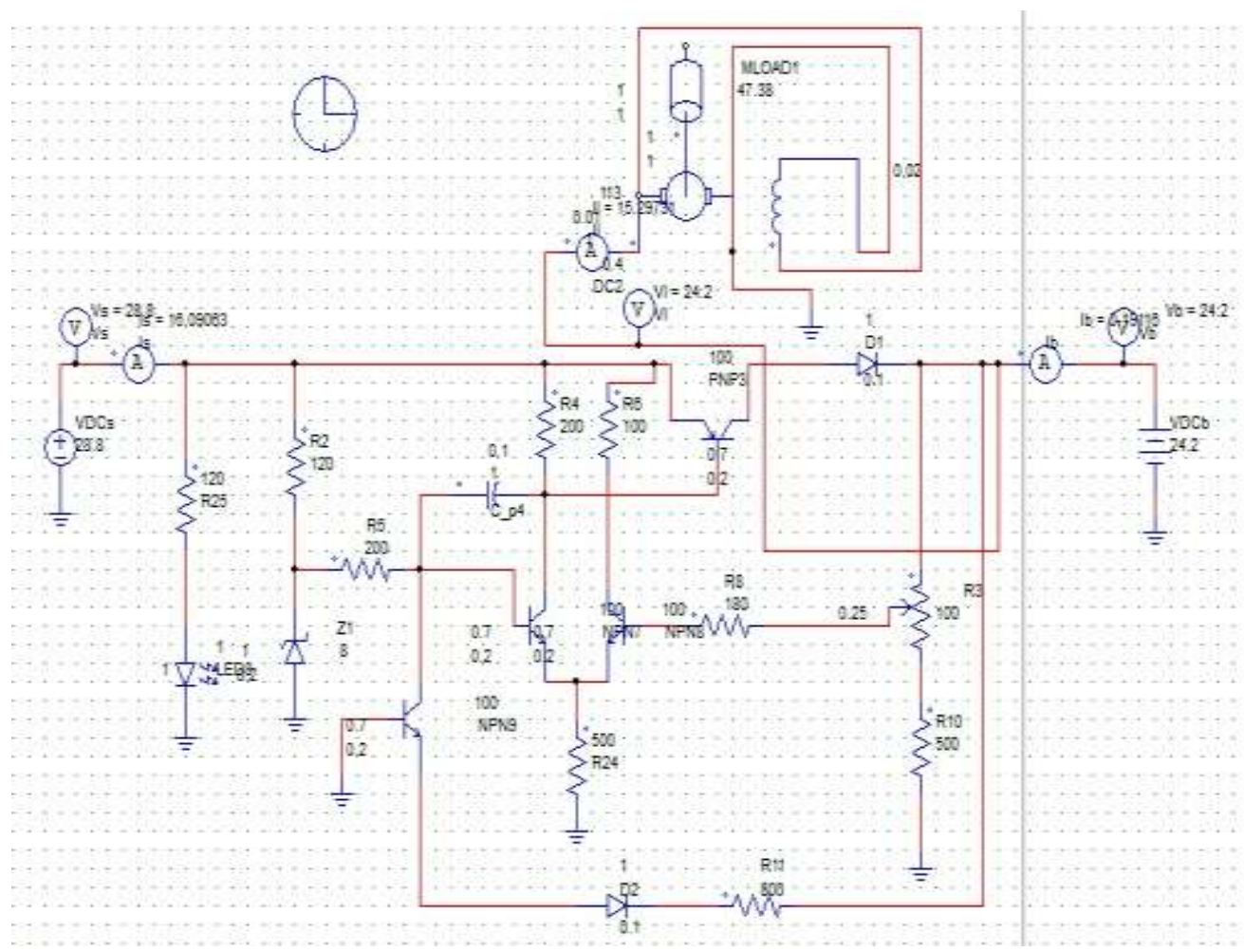

Fig. 7 Schematic Diagram of the Integrated System with Solar Charge Controller

As seen from above three figures, the voltage and current waveforms are uncontrolled in nature. Fig. 7 shows the PSIM model of the integrated system including the solar charge controller. 


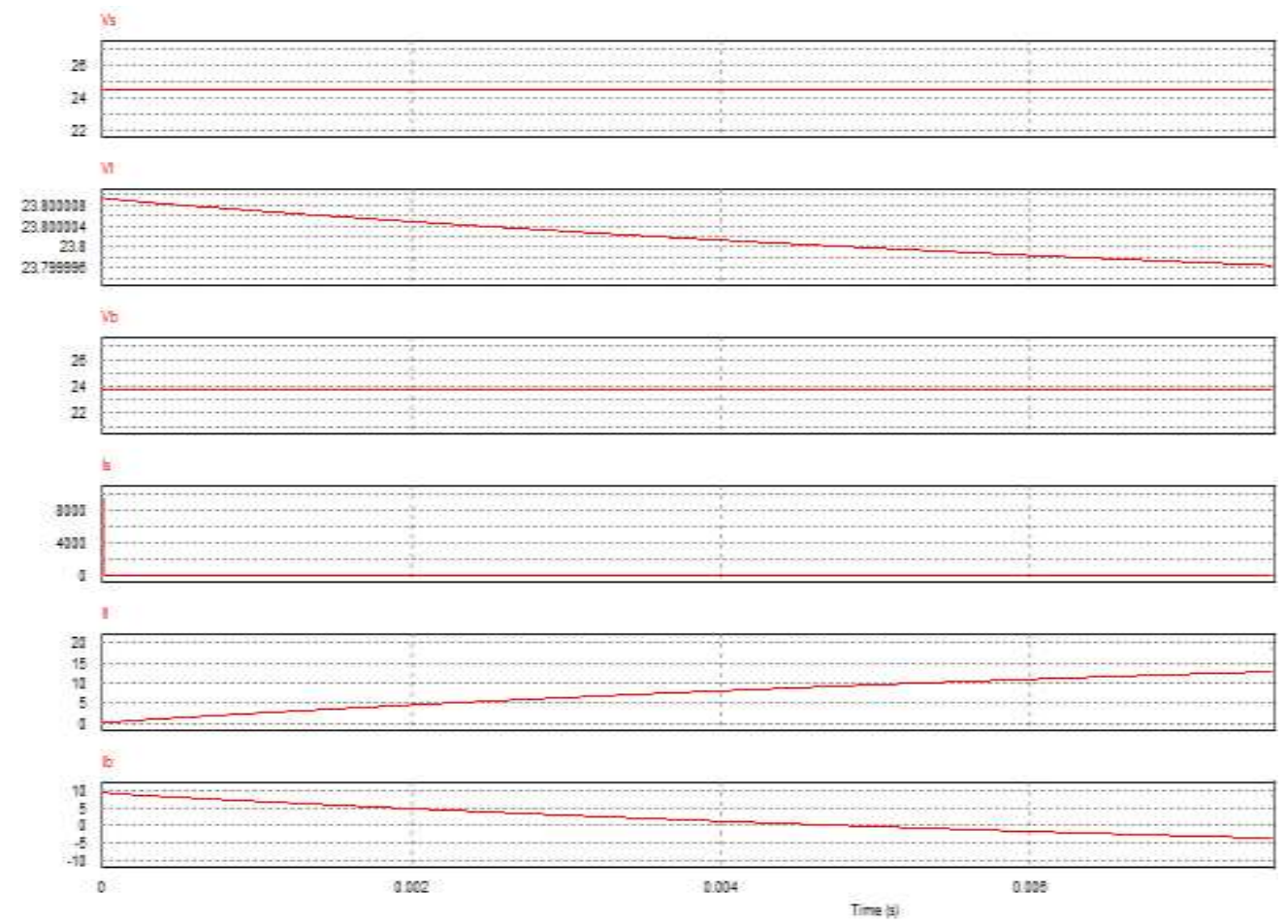

Fig. 8 Voltage and Current Waveforms with Solar Charge Controller for Solar Panel Voltage 24.3 Volt

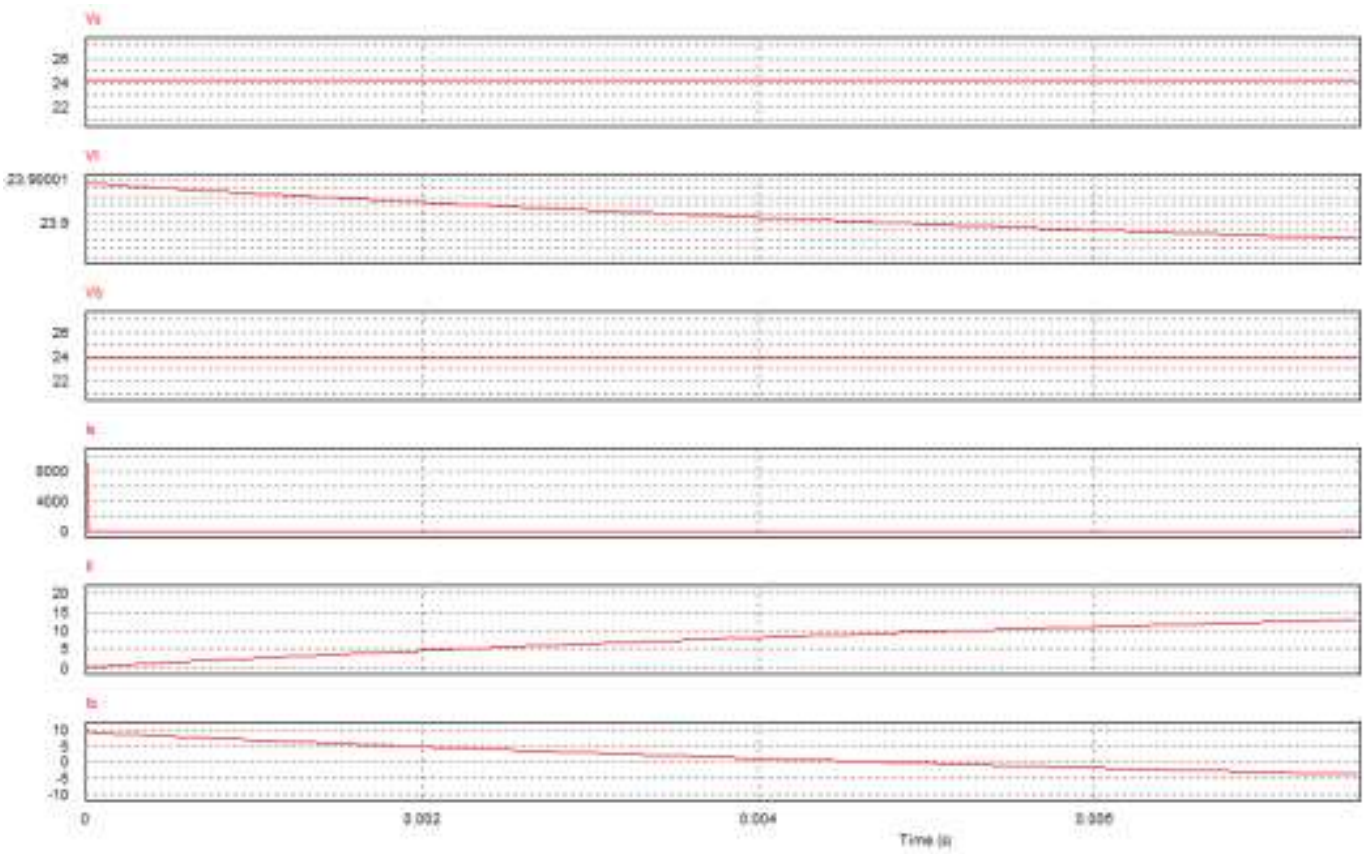

Fig. 9 Voltage and Current Waveforms with Solar Charge Controller for Solar Panel Voltage 28.4 Volt 


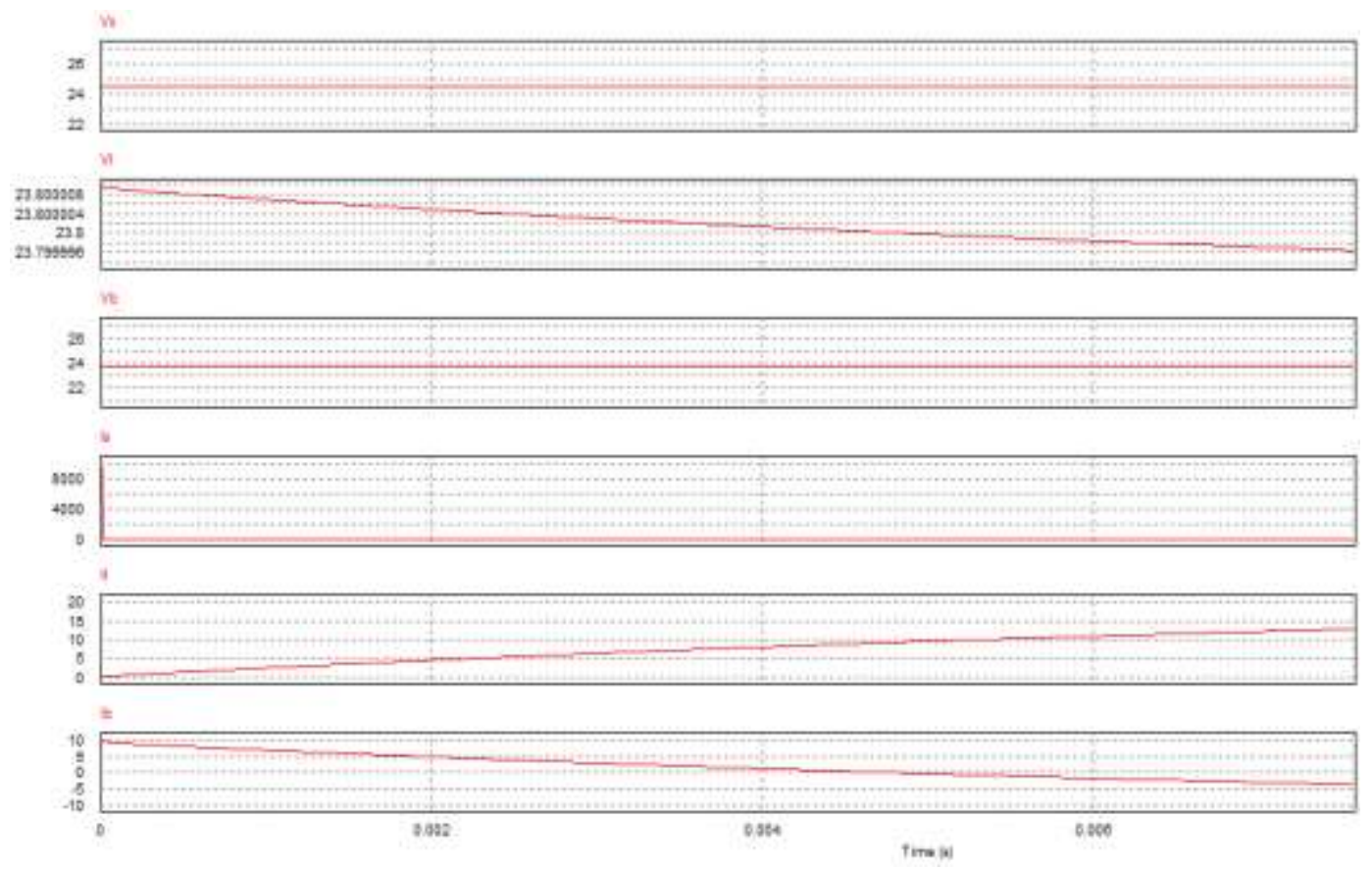

Fig. 10 Voltage and Current Waveforms with Solar Charge Controller for Solar Panel Voltage 25.6 Volt.

Figures 8-10 show the corresponding voltage and current waveforms for the three conditions mentioned above in presence of the solar charge controller. As seen from above three figures, the voltage and current waveforms are controlled by the charge controller maintaining steady values suitable for smooth operation of the DC shunt motor.

\section{EXPERIMENTAL RESULTS AND DISCUSSION}

The integrated system has been implemented in real time and Fig. 11 displays such system. It includes the PV panel, a charge controller, batteries and the DC shunt motor. The elevator door is capable of forward and backward movement at a speed of $200 \mathrm{rpm}$.

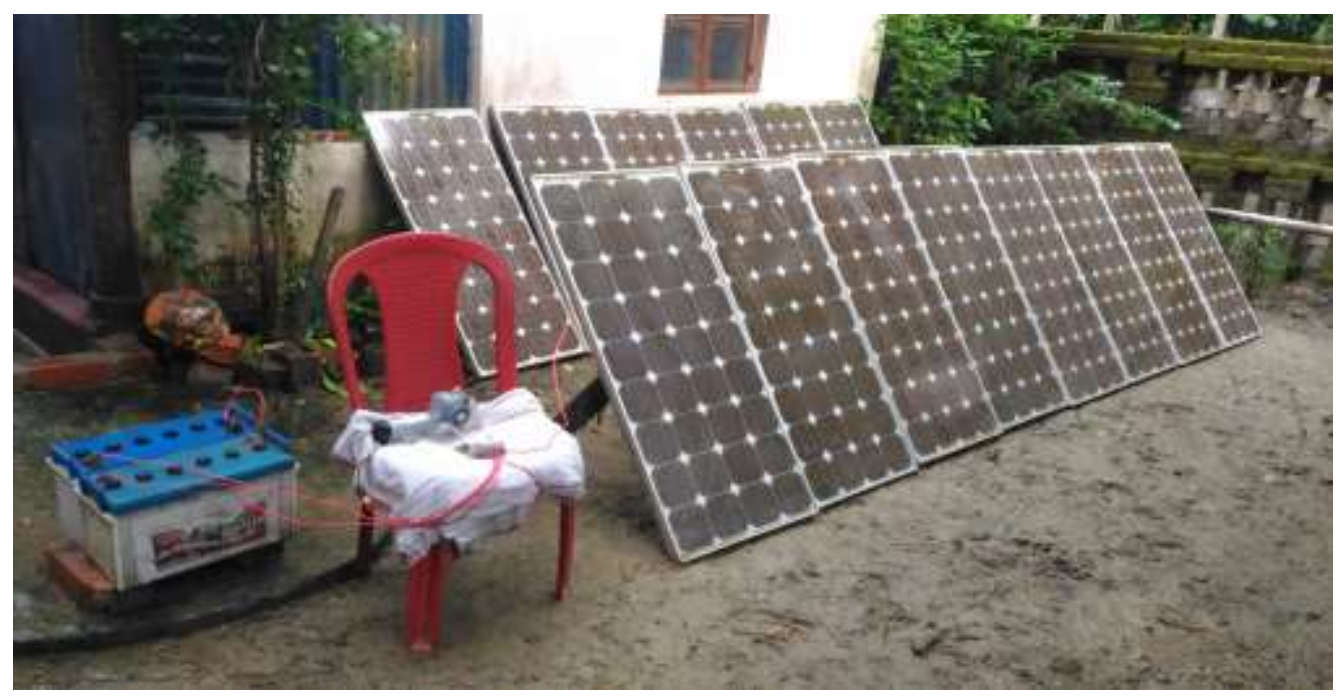

Fig. 11 Components of the Integrated PV System for Elevator Door Operation 


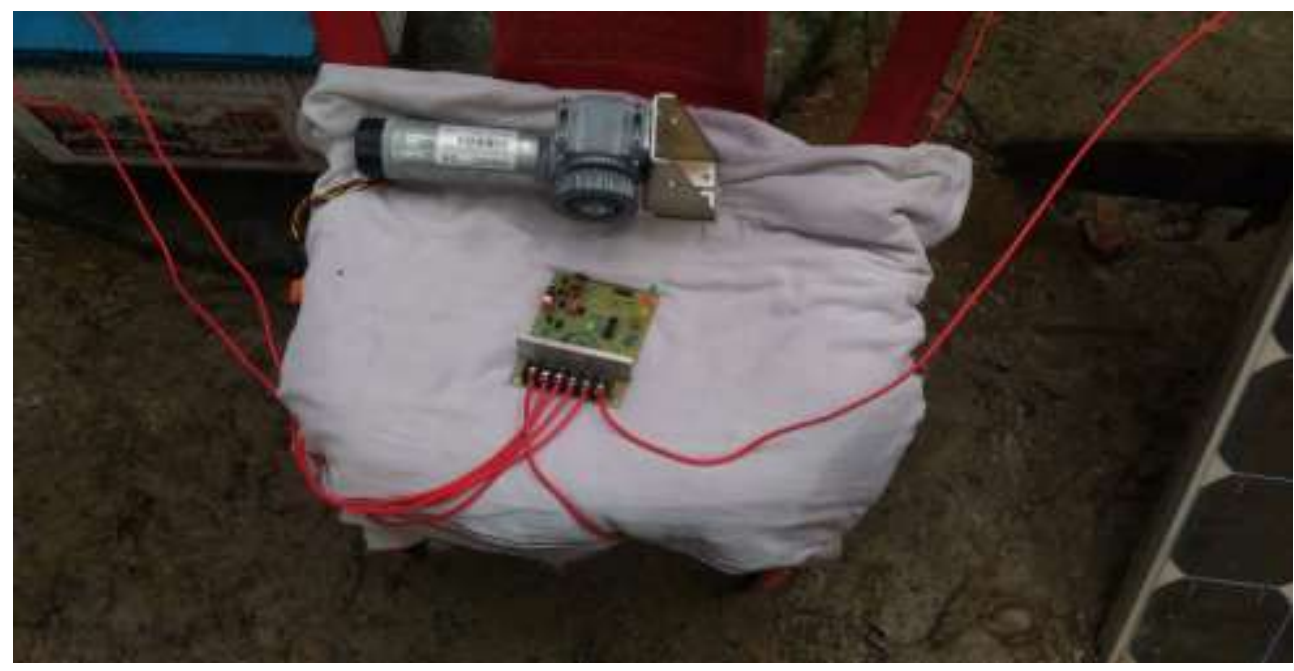

Fig. 12 The Solar Charge Controller and the DC Shunt Motor

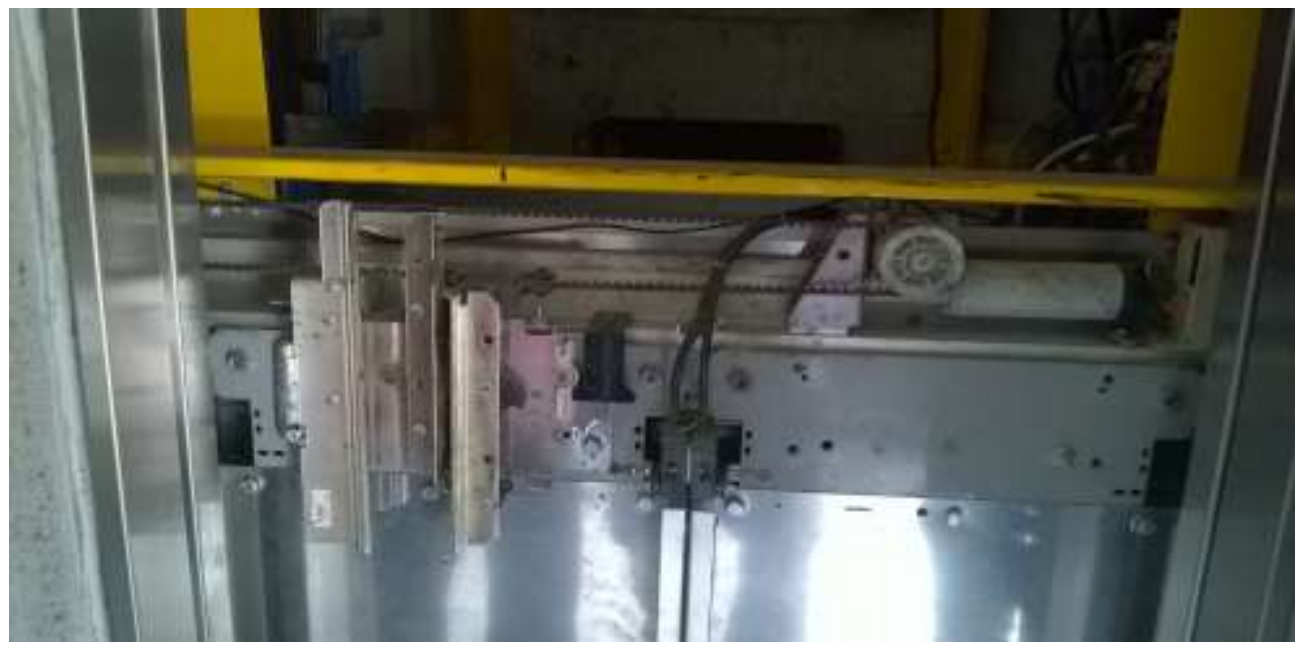

Fig. 13. The Elevator and DC Shunt Motor on Top of Elevator Roof for Elevator Door Control

During the experiment, voltage and current values have been measured at different terminals and the armature torque of the DC shunt motor controlling the elevator door has been observed. Table II gives the measured values. Armature torque has been calculated using the formula

$$
T=9.55 \frac{V I}{N}
$$

\section{Where}

$\mathrm{T}=$ Armature torque

$\mathrm{V}=$ Motor Voltage

$\mathrm{I}=$ Load Current

$\mathrm{N}=$ Speed of the elevator door $=200 \mathrm{rpm}$

The specifications of measuring instruments are mentioned in Table III. The calibration of all the instruments used in the experiment are free from any uncertainty. 
Table II. Voltage, current and armature torque values

\begin{tabular}{|c|c|c|c|c|c|c|}
\hline $\begin{array}{c}\text { Sl. } \\
\text { No. }\end{array}$ & $\begin{array}{c}\text { Solar panel } \\
\text { voltage } \\
(\text { Volt })\end{array}$ & $\begin{array}{c}\text { Battery } \\
\text { voltage } \\
(\text { Volt })\end{array}$ & $\begin{array}{c}\text { Load } \\
\text { voltage } \\
(\text { Volt })\end{array}$ & $\begin{array}{c}\text { Load } \\
\text { current } \\
(\mathbf{A m p})\end{array}$ & $\begin{array}{c}\text { Motor } \\
\text { voltage } \\
(\text { Volt })\end{array}$ & $\begin{array}{c}\text { Armature } \\
\text { torque T } \\
(\mathbf{N}-\mathbf{m})\end{array}$ \\
\hline 1 & 24.3 & 24.32 & 24.30 & 41.14 & 24.20 & 47.73 \\
\hline 2 & 24.5 & 24.00 & 23.90 & 41.65 & 23.95 & 47.74 \\
\hline 3 & 26.2 & 24.15 & 24.16 & 41.40 & 24.15 & 47.74 \\
\hline 4 & 27.3 & 24.20 & 24.30 & 41.24 & 24.08 & 47.77 \\
\hline 5 & 28.8 & 23.95 & 23.95 & 41.74 & 23.93 & 47.74 \\
\hline 6 & 28.4 & 23.90 & 23.92 & 41.84 & 23.92 & 47.74 \\
\hline 7 & 25.9 & 24.14 & 24.15 & 41.40 & 24.14 & 47.74 \\
\hline 8 & 26.7 & 24.35 & 24.35 & 41.06 & 24.34 & 47.74 \\
\hline 9 & 27.9 & 24.30 & 24.30 & 41.14 & 24.20 & 47.73 \\
\hline 10 & 25.6 & 24.25 & 24.25 & 41.25 & 24.25 & 47.76 \\
\hline
\end{tabular}

Table III. Instrument Specifications

\begin{tabular}{|c|c|c|c|c|c|}
\hline SI & Instrument & Type & Range/Rating & Accuracy & Maximum Resolution \\
\hline \multirow{3}{*}{1} & \multirow{3}{*}{ Multimeter } & \multirow{3}{*}{$\begin{array}{l}\text { Digital } \\
\text { (FLUKE } \\
179 \text { TRUE } \\
\text { RMS } \\
\text { DIGITAL } \\
\text { MULTIM } \\
\text { ETER) }\end{array}$} & $\begin{array}{l}\text { Max DC voltage } \\
1000 \mathrm{v}\end{array}$ & $\begin{array}{l}\text { DC Voltage: } \\
\pm(0.09 \%+2)\end{array}$ & DC Voltage $0.1 \mathrm{mV}$ \\
\hline & & & $\begin{array}{l}\text { Max AC } \\
\text { voltage1000 v }\end{array}$ & $\begin{array}{l}\text { AC Voltage: } \\
\pm(0.09 \%+2)\end{array}$ & AC Voltage $0.1 \mathrm{mV}$ \\
\hline & & & $\begin{array}{l}\text { Temperature } \\
-40^{\circ} \mathrm{C} / 400^{\circ} \mathrm{C}\end{array}$ & $\begin{array}{l}\text { Temperature: } \\
\pm(1.0 \%+2)\end{array}$ & Temperature : $0.1^{\circ} \mathrm{C}$ \\
\hline 2 & Ammeter & $\begin{array}{l}\begin{array}{l}\text { Digital } \\
\text { (Bayite) }\end{array} \\
\end{array}$ & $0 / 100 \mathrm{~A}$ & $1 \%$ & $0.01 \mathrm{~mA}$ \\
\hline
\end{tabular}

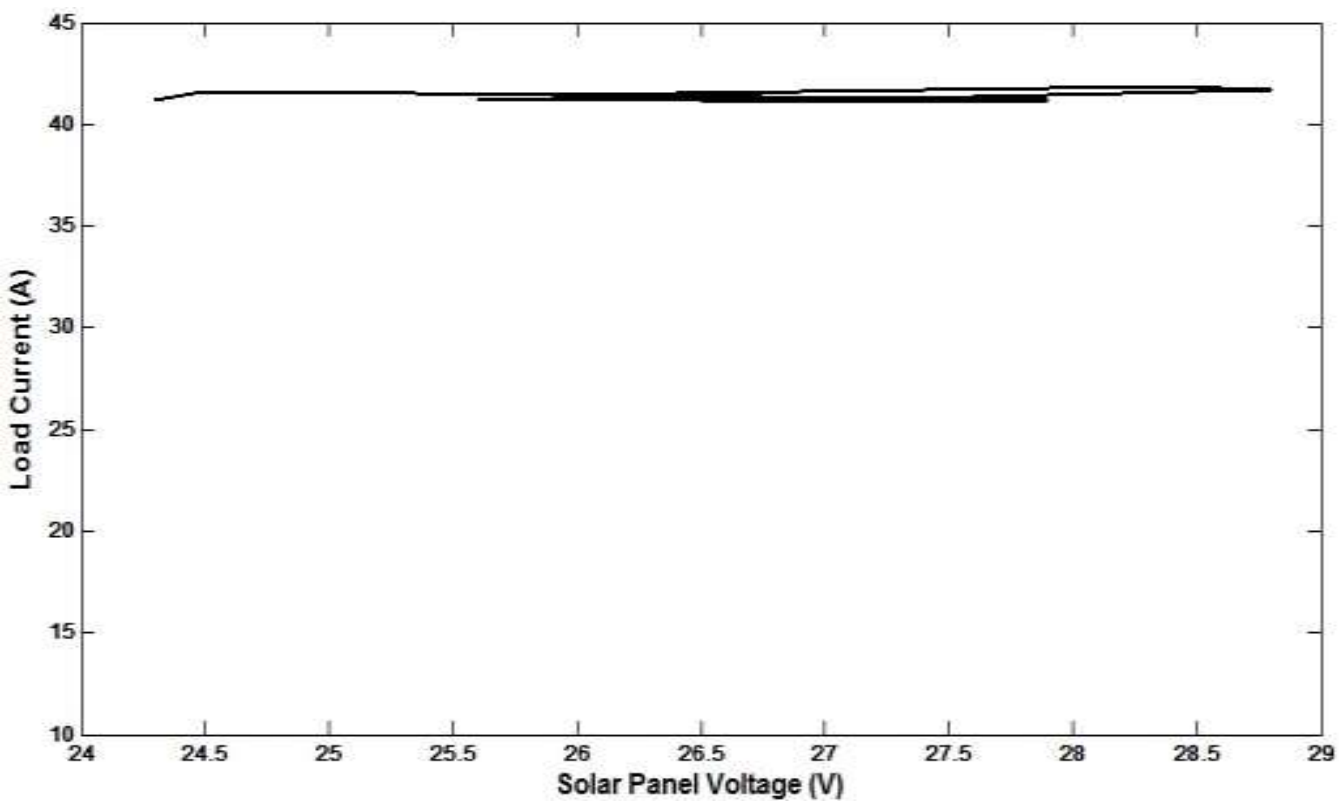

Fig. 14 Load Current vs. Solar Panel Voltage 


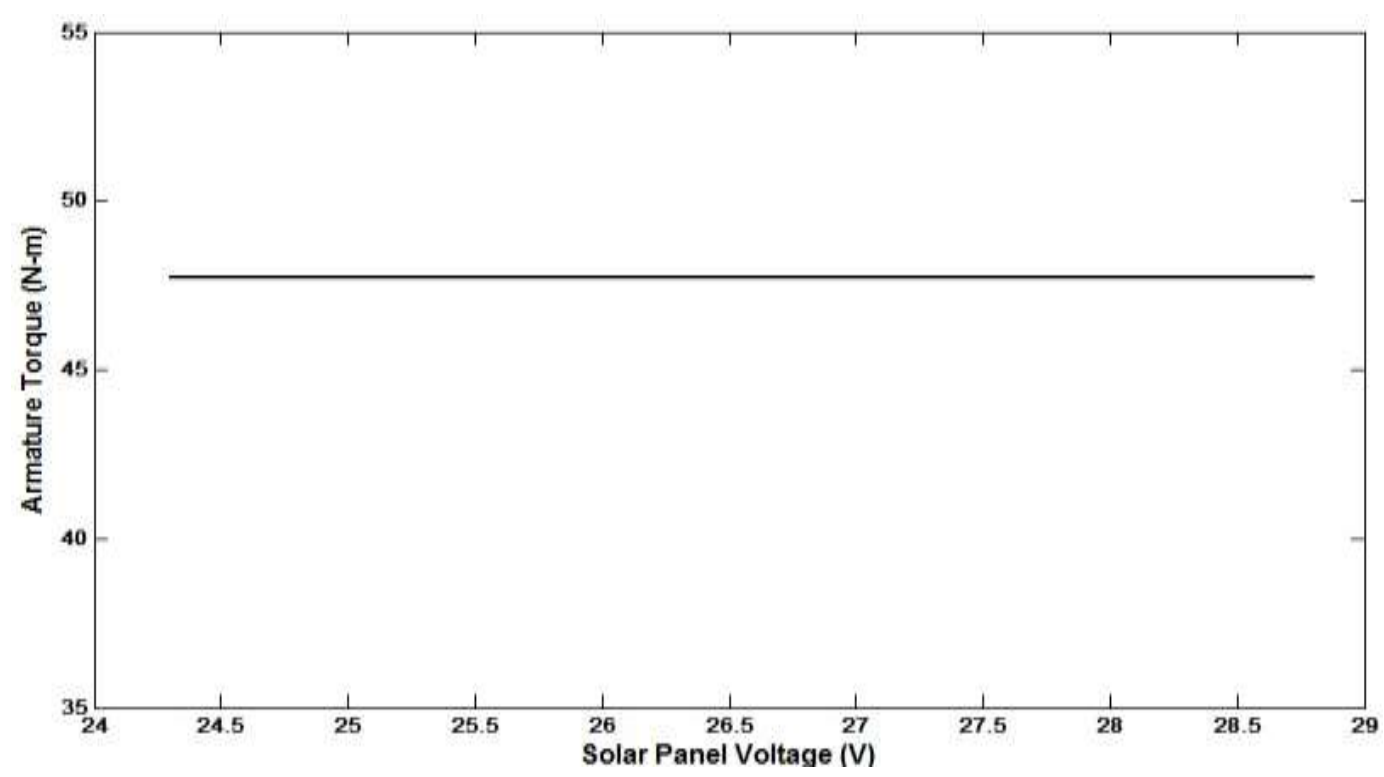

Fig. 15 Armature Torque vs. Solar Panel Voltage

The experimental results show that the integrated system is performing as expected. Fig. 14 shows the variation of load current with solar panel voltage, whereas Fig. 15 shows the armature torque profile against solar panel voltage variation. The load current variation is negligible and the armature torque of the DC shunt motor responsible for elevator door operation almost remains steady. The integrated system is capable of driving the elevator door smoothly with the help of the solar PV system and solar energy can be used as a source of energy for the elevator door motor and its proper functioning; thereby, eliminating the need of electrical energy for driving the elevator door motor.

\section{CONCLUSION}

A solar PV integrated system for elevator door operation has been simulated using PSIM and built in real time to test the feasibility of the proposed system. Experiments have been performed at different conditions and experimental results are in line with the simulated results. It can be concluded that the solar PV panel will supply the required energy to run the elevator door motor and for proper functioning of the elevator door. This implementation has several benefits. Since solar energy is driving the door motor, during power cut even if the elevator doesn't run, the doors will continue to open and close and people stuck inside the elevator can come of the elevator without difficulties. Also the use of renewable energy like solar energy will minimize greenhouse gas emission. Such system is cost effective as well since only installation cost is present, but the maintenance cost is minimal. In this study $1 \mathrm{~kW}$ motor has been considered, whereas future scope of the work may include building similar systems with more powerful DC shunt motors as required.

\section{REFERENCES}

[1] S. Rahman, Alternative Energy Sources: The Quest for Sustainable Energy, IEEE Power and Energy Magazine (2007).

[2] R. Foster, M. Ghassemi, A. Cota, Solar energy: renewable energy and the environment, CRC Press (2009).

[3] S. Mirić, M. Nedeljković, The Solar Photovoltaic Panel Simulator, Rev. Roum. Sci. Techn. Électrotechn. et Énerg., 60, 3, pp. 273-281 (2015).

[4] R. Kumar, B. Singh, Buck boost converter fed BLDC motor drive for PV array based water pumping, IEEE International Conference on Power Electronics, Drives and Energy Systems (PEDES), pp.1-6, 16-19 (2014). 
[5] H. Wang, D. Zhang, The stand-alone PV generation system with parallel battery charger, Proc. Int. Conf. Elect. Control Eng. (ICECE'10), pp. 4450-4453 (2010).

[6] M. Kolhe, Techno-economic optimum sizing of a stand-alone solar photovoltaic system, IEEE Trans. Energy Convers., 24, 2, pp. 511-519 (2009).

[7] D. Debnath, K. Chatterjee, A two stage solar photovoltaic based standalone scheme having battery as energy storage element for rural deployment, IEEE Trans. Ind. Electron., 62, 7, pp. 4148-4157 (2015).

[8] S. Krithiga, N. G. A. Gounden, Power electronic configuration for the operation of PV system in combined grid-connected and stand-alone modes, IET Power Electron., 7, 3, pp. 640-647 (2014).

[9] I. J. Balaguer-Álvarez, E. I. Ortiz-Rivera, Survey of distributed generation islanding detection methods, IEEE Latin Amer. Trans., 8, 5, pp. 565-570 (2010).

[10] C. A. Hill, M. C. Such, D. Chen, J. Gonzalez, W. M. Grady, Battery energy storage for enabling integration of distributed solar power generation, IEEE Trans. Smart Grid, 3, 2, pp. 850-857 (2012).

[11] W. Xiao, F. F. Edwin, G. Spagnuolo, J. Jatskevich, Efficient approaches for modeling and simulating photovoltaic power systems, IEEE J. Photovoltaics, 3, 1, pp. 500-508 (2013).

[12] S. Jain, A.K. Thopukara, R. Karampuri, V.T. Somasekhar, A Single-Stage Photovoltaic System for a Dual-Inverter-Fed Open-End Winding Induction Motor Drive for Pumping Applications, IEEE Transactions on Power Electronics, 30, 9, pp. 4809-4818 (2015).

[13] Le An, D.D.-C. Lu, Design of a Single-Switch DC/DC Converter for a PV-Battery-Powered Pump System with PFM+PWM Control, IEEE Transactions on Industrial Electronics, 62, 2, pp. 910-921 (2015).

[14] Q. Yan, X. Wu, X. Yuan, Y. Geng, Q. Zhang, Minimization of the DC Component in Transformer less Three-Phase Grid-Connected Photovoltaic Inverters, IEEE Trans. Power Elec., 30, 7, pp. 3984-3997 (2015).

[15] 15. A. Sangwongwanich, Y. Yang, F. Blaabjerg, High-Performance Constant Power Generation in GridConnected PV Systems, IEEE Trans. Power Elec., 31, 3, pp. 1822-1825 (2016).

[16] L. Campanhol, S. Silva, A. Junior, V. Bacon, Dynamic performance improvement of a grid-tied PV system using a feed-forward control loop acting on the NPC inverter currents, IEEE Trans. Ind. Elec., 64, 3, pp. 2092-2101 (2017).

[17] A. Radwan, Y. Mohamed, Power Synchronization Control for Grid-Connected Current-Source InverterBased Photovoltaic Systems, IEEE Trans. Energy Conv., 31, 3, pp. 1023-1036 (2016).

[18] G. N. Tiwari, S. Dubey, Fundamentals of Photovoltaic Modules and Their Applications, Centre for Energy Studies, Indian Institute of Technology (IIT) Delhi, New Delhi, India, RSC publishing, pp. 99100 (2010).

[19] P. Singh, N.M. Ravindra, Temperature dependence of solar cell performance - an analysis, Solar Energy Materials \& Solar Cells, 101, pp. 36-45 (2012)

[20] A. M. Nader, D. Abderrahmane, A. Said, Optimization of the performance of a photovoltaic pumping system by neuro fuzzy and direct torque control, Rev. Roum. Sci. Techn. - Électrotechn. et Énerg., 59, 3, pp. 279-289 (2014). 